\section{MANAJEMEN PELAYANAN KEPERAWATAN BEDAH DI RUMAH SAKIT}

Buku ini berisi tentang Tentang Proses Manajemen Pelayanan Keperawatan Bedah di Rumah Sakit dimana masih banyaknya Rumah Sakit yang masih kurang dalam hal pelayanan dan standar yang ada sedangkan Rumah sakit sebagai fasilitas kesehatan sangat penting perannya. Di Indonesia, Rumah Sakit memiliki peran sebagai rujukan akhir. Sebagai tempat pemulihan dan perawatan kesehatan, Rumah Sakit harus mampu memberikan pelayanan terbaik. Pelayanan kesehatan yang terbaik harus sesuai dengan kebutuhan pasien. Tim keperawatan yang bertugas juga harus dibekali pembekalan yang baik tentang manajemen rumah sakit salah satu diantaranya Manajemen Pelayanan Keperawatan di Ruang Bedah sesuai dengan definisi Manajemen pelayanan keperawatan yaitu suatu proses perubahan atau tranformasi dari sumber daya yang dimiliki untuk mencapai tujuan pelayanan keperawatan melalui pelaksanaan fungsi perencanaan, pengorganisasian, pengaturan, ketenagaan, pengarahan, evaluasi dan pengendalian mutu. Oleh karenanya Buku ini Hadir sebagai Referensi bacaan bagi Akademisi (Dosen), praktisi (Perawat) serta Mahasiwa Keperawatan dalam menambah pengetahuan tentang Manajemen Pelayanan Keperawatan Bedah.

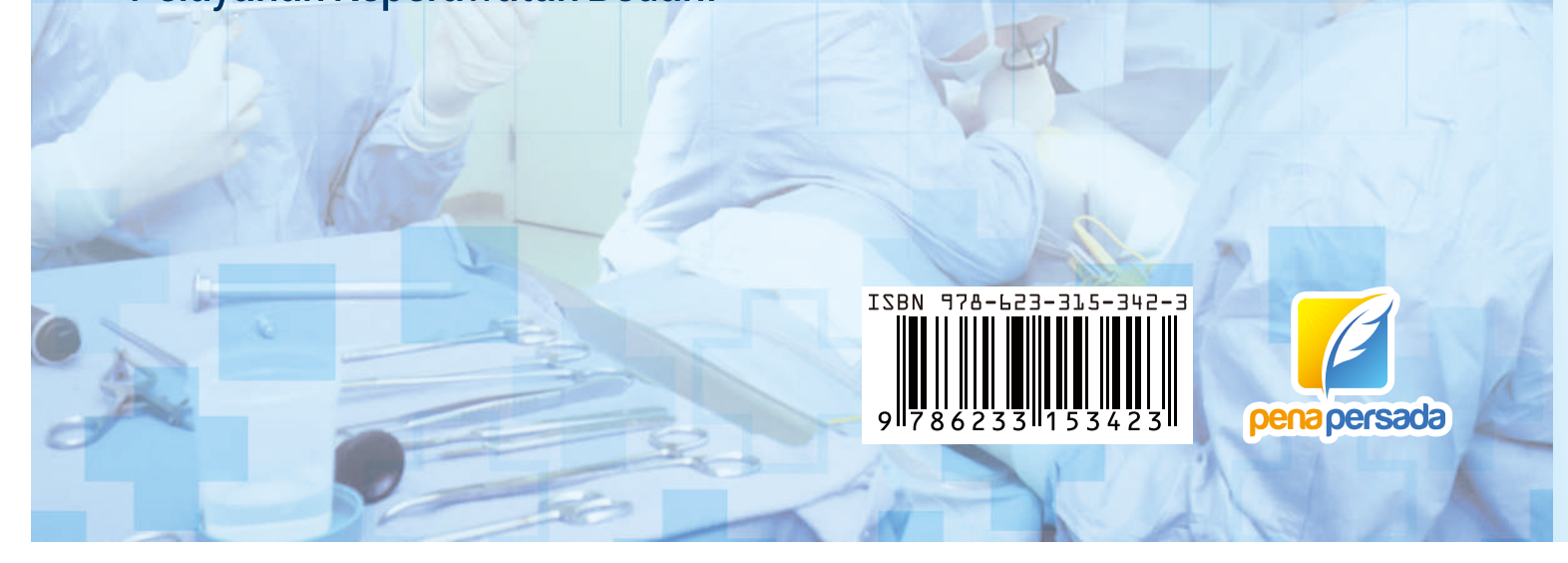

를

Dr. Harniati.,S.Kep.,Ns.,M.Kes.,M.Si Risnawati.,S.Kep.,Ns.,M.Kes

\section{MANAJEMEN PELAYANAN} KEPERAWATAN BEDAH DI RUMAH SAKIT

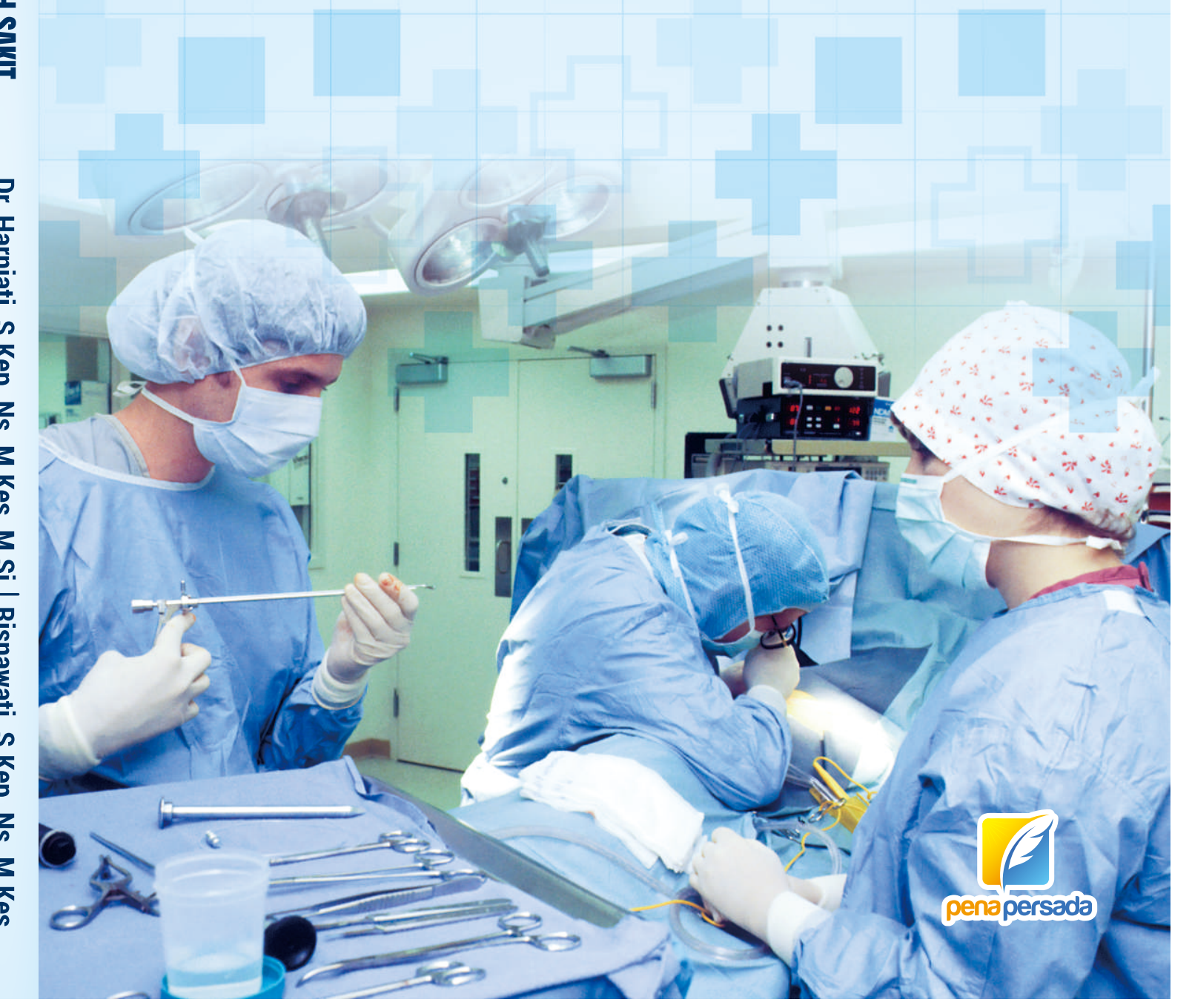




\section{MANAJEMEN PELAYANAN \\ KEPERAWATAN BEDAH DI RUMAH SAKIT}

Dr. Harniati.,S.Kep.,Ns.,M.Kes.,M.Si

Risnawati.,S.Kep.,Ns.,M.Kes

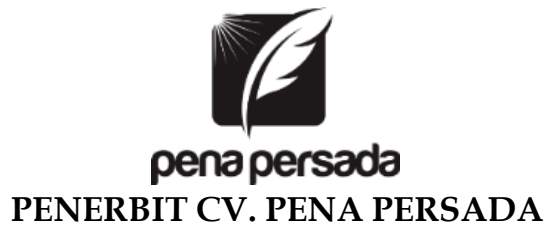




\title{
MANAJEMEN PELAYANAN KEPERAWATAN BEDAH DI
} RUMAH SAKIT

\author{
Penulis: \\ Dr. Harniati.,S.Kep.,Ns.,M.Kes.,M.Si \\ Risnawati.,S.Kep.,Ns.,M.Kes
}

ISBN : 978-623-315-342-3

Editor:

Wiwit Kurniawan

Design Cover :

Retnani Nur Briliant

Layout :

Eka Safitry

Penerbit CV. Pena PersadaRedaksi :

Jl. Gerilya No. 292 Purwokerto Selatan, Kab. BanyumasJawa

Tengah

Email : penerbit.penapersada@gmail.com Website :

penapersada.com Phone : (0281) 7771388

\section{Anggota IKAPI}

All right reserved Cetakan pertama : 2021

Hak Cipta dilindungi oleh undang-undang. Dilarang memperbanyak karya tulis ini dalam bentuk apapun tanpaizin penerbit 


\section{PRAKATA}

Segala puji senantiasa kita panjatkan kehadirat Allah Swt, atas segala rahmat dan karunianya, akhirnya penulis dapat menyelesaikan penyusunan buku yang berjudul "MANAJEMEN PELAYANAN KEPERAWATAN BEDAH DI RUMAH SAKIT".Kami menyadari bahwa tanpa bantuan dan bimbingan dari berbagai pihak sangatlah sulit bagi saya untuk menyelesaikan karya ini. Oleh karena itu, kami mengucapkan banyak terima kasih pada semua pihak yang telah membantu penyusunan buku ini. Sehingga buku ini bisa hadir di hadapan pembaca.

Dalam buku ini akan dibahas tentang Konsep Manajemen, Fumgsi dan proses serta analisis manajemen serta bagaimana Proses Manajemen Pelayanan Keperawatan Bedah di Salah satu Rumah Sakit dan semoga buku ini bisa menjadi Referensi bacaan bagi Mahasiwa Keperawatan ataupun Akademisi (Dosen) dalam menambah pengetahuan Manajemen Pelayanan Keperawatan Bedah.

Penulis menyadari bahwa buku ini masih jauh dari kesempurnaan. Oleh karena itu kritik dan saran yang membangun sangat dibutuhkan guna penyempurnaan buku ini. Akhir kata kami berharap Allah Swt berkenan membalas segala kebaikan semua pihak yang telah membantu

Penulis 


\section{DAFTAR ISI}

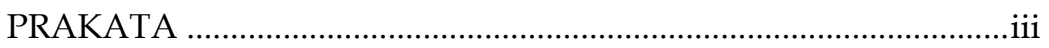

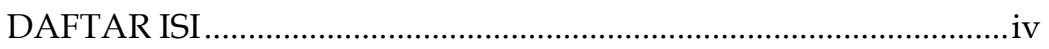

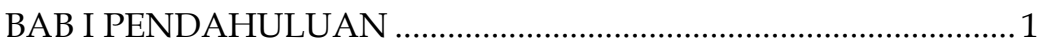

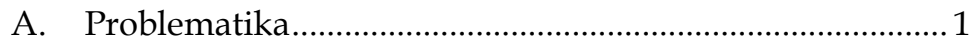

B. Mengapa Buku ini di tulis ................................................. 2

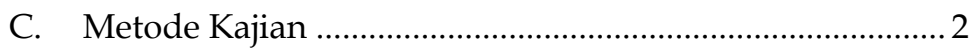

BAB II KONSEP MANAJEMEN ...................................................... 3

A. Konsep Manajemen Dalam Konteks Administrasi Publik ……........................................................... 3

B. Teori dan Perspektif Manajemen ...........................................10

a. Teori Insentif .................................................................. 10

b. Teori Hubungan Manusia ……………………………..... 10

c. Teori Perilaku ................................................................... 10

BAB III PERKEMBANGAN GENERASI DAN PEMIKIRAN

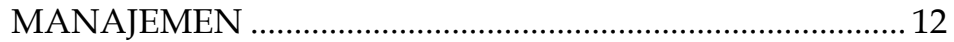

A. Generasi I (Jungle Management) ……………………….... 12

B. Generasi II (Management by direction) ..............................12

C. Generasi III (Management bytargetting/management by

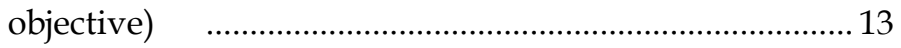

D. Generasi IV (Value creative management) ........................13

E. Generasi V (Knowledge and human networking management) .................................................................... 14

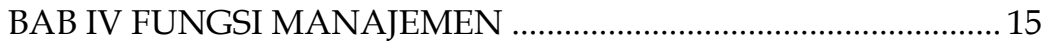

A. Prinsip-prinsip Manajemen ................................................ 17

B. Unsur-Unsur Manajemen ..................................................... 18 
C. Kelompok Manajemen............................................................ 19

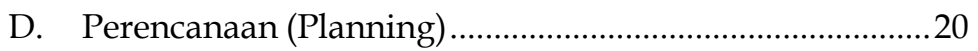

E. Pengorganisasian (Organizing) ……………………..........26

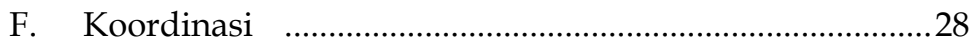

BAB V PERSPEKTIF VALUE CREATIVE DALAM KONSEP TOTAL QUALITYMANAGEMENT .........................................

A. Pengertian ………………………………………............

B. Elemen Pokok Total Quality Management........................32

1. Fokus pada Pelanggan (Customer Focussed) ..............32

2. Keterlibatan Karyawan secara Keseluruhan (Total Employee Involvement).................................................32

3. Pemusatan perhatian pada Proses (Process-centered) 32

4. Sistem yang Terintegrasi (Integrated System) .............33

5. Pendekatan Strategi dan Sistematik (Strategy and Systematic Approach) ......................................................33

6. Peningkatan yang berkesinambungan (Continual Improvement) .......................................................................

7. Keputusan berdasarkan Fakta (Fact-based decision making) ...........................................................................33

8. Komunikasi (Communications) …………………..........34

BAB VI MANAJEMEN PROSES DAN ANALISIS MANAJEMEN35

A. Definisi dan Kontribusi Empiris............................................35

B. Langkah-Langkah Perbaikan Proses ...................................38

C. Pengertian Analisis .................................................................43

D. Teknik Analisis Data ............................................................. 43

E. Langkah Langkah Teknik Analisis Data ..............................4 44

BAB VII INDIKATOR KINERJA PELAYANAN RUMAH SAKIT 45

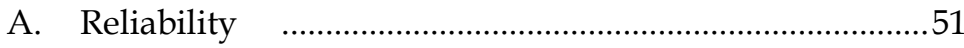




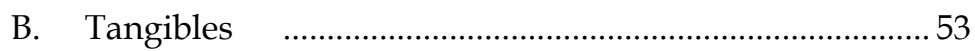

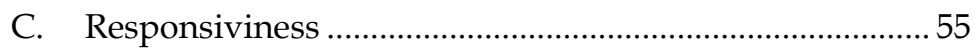

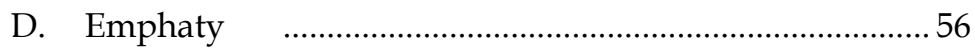

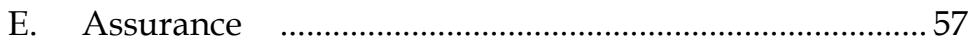

F. Confidence (kepercayaan) ……………………………..... 58

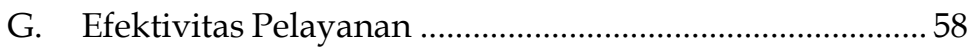

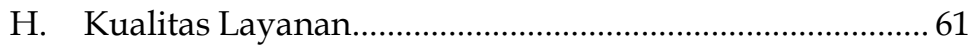

BAB VIII KONSEP RUMAH SAKIT DAN KONSEP HUMAN

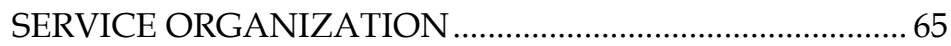

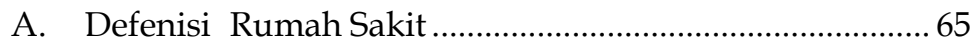

B. Standar Pelayanan Rumah Sakit ............................................ 77

C. Human Service Organization ................................................ 79

BAB IX PROSES MANAJEMEN PELAYANAN KEPERAWATAN BEDAH DI RUMAH SAKIT ……………………….............. 85

A. Pengawasan 'Manajemen Pelayanan Keperawatan Bedah'

B. Model Proses Bisnis 'Manajemen PelayananKeperawatan Bedah'

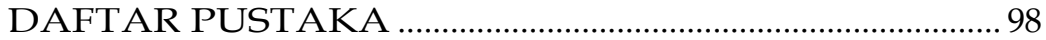

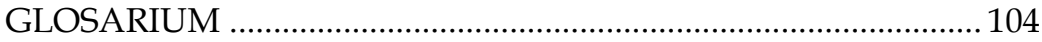

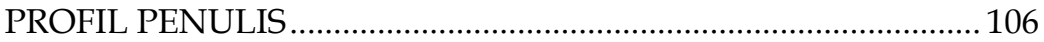




\section{BAB I \\ PENDAHULUAN}

\section{A. Problematika}

Meningkatnya tuntutan masyarakat akan sarana kesehatan terutama di Rumah Sakit, secara berkesinambungan membuat Rumah Sakit harus melakukan upaya peningkatan mutu pemberian pelayanan kesehatan dimana salah satunya adalah proses pelayanan Manajemen Keperawatan sedangkan Rumah Sakit merupakan sarana penyedia layanan kesehatan untuk masyarakat. Rumah Sakit sebagai institusi penyedia jasa pelayanan kesehatan perorangan secara paripurna memiliki peran yang sangat strategis untuk mewujudkan derajat kesehatan yang setinggitingginya (UndangUndang Republik Indonesia Nomor 44 tahun 2009). Rumah Sakit dituntut untuk memberikan pelayanan yang bermutu sesuai dengan standar yang ditetapkan dan dapat menjangkau seluruh lapisan masyarakat.

Dalam konteks manajemen, pelayanan keperawatan khususnya Di Ruang Perawatan Bedah merupakan suatu proses yang dapat didefinisikan sebagai integrasi sekuensial dari orang, material, metode, dan mesin atau peralatan, dalam suatu lingkungan guna menghasilkan nilai tambah out put untuk pelanggan (Gaspersz, 2007; Becker, Kugeler, and Rosemann, 2003). Dalam manajemen keperawatan bedah, proses manajemen mengkonversi in put terukur menjadi out put terukur melalui sejumlah langkah sekuensial yang terorganisir sebagaimana tertuang dalam SOP bedah.

Pandangan terhadap manajemen keperawatan bedah seperti itu merupakan hasil dari pendekatan proses. Pendekatan proses sebagai salah satu opsi perlakuan dalam analisis manajemen, relevan dengan orientasi kajian dalam buku ini. Orientasi mekanis dari pendekatan proses terhadap 
manajemen seperti itu ditujukan sebagai usaha perbaikan yang berkesinambungan. Manfaatnya dapat menghasilkan mutu barang atau jasa yang sesuai dengan tuntutan pelanggan dan dapat memenangkan persaingan yang didukung secara subordinatif oleh manajemen pelayanan keperawatan bedah. Dalam konteks pelayanan, manajemen keperawatan bedah merupakan salah satu varian urusan pokok (core business) rumah sakit.

\section{B. Mengapa Buku ini di tulis}

Buku ini ditulis mengingat masih begitu banyaknya Rumah Sakit yang masih kurang dalam hal pelayanan dan standar yang ada dimana Rumah sakit sebagai fasilitas kesehatan sangat penting perannya. Di Indonesia, Rumah Sakit memiliki peran sebagai rujukan akhir. Sebagai tempat pemulihan dan perawatan kesehatan, Rumah Sakit harus mampu memberikan pelayanan terbaik. Pelayanan kesehatan yang terbaik harus sesuai dengan kebutuhan pasien. Tim keperawatan yang bertugas juga harus dibekali pembekalan yang baik tentang manajemen rumah sakit salah satu diantaranya Manajemen Pelayanan Keperawatan di Ruang Bedah sesuai dengan definisi Manajemen pelayanan keperawatan yaitu suatu proses perubahan atau tranformasi dari sumber daya yang dimiliki untuk mencapai tujuan pelayanan keperawatan melalui pelaksanaan fungsi perencanaan, pengorganisasian, pengaturan, ketenagaan, pengarahan, evaluasi dan pengendalian mutu.

\section{Metode Kajian}

Kajian dalam buku ini berupaya mendefenisikan masalah dalam konteks model perbaikan proses, dimulai dari penetapan atau spesifikasi sistem mana yang akan dituju agar usaha dapat terfokus pada proses bukan pada out put. Karena itu pula seluruh komponen pokok manajemen, dikaji mulai dari in put, proses, out put, control (baik dalam konteks terbatas, manajemen pelayanan keperawatan bedah maupun dalam konteks besar, manajemen keperawatan bedah dan evaluation. 


\section{BAB II \\ KONSEP MANAJEMEN}

\section{A. Konsep Manajemen Dalam Konteks Administrasi Publik}

Sejak awal, perspektif administrasi klasik sudah memberi perhatian pada corak manajemen yang fokus pada efisiensi yang terkoordinir pada instansi (pelayanan) pemerintah. Namun efisiensi yang dibangun melalui paradigma administrasi klasik masih mengandalkan pendekatan ekonomis, sebagaimana diistilahkan dalam paradigma tersebut sebagai efisiensi mekanis. Hadirnya gagasan Frederickson antara tahun 1960-1970 (2003) memberi tekanan pada nilai baru „keadilan sosial" sehingga lahirlah konsepsi New public administration yang kemudian diklaim sebagai pergeseran paradigma administrasi publik. Terlepas dari apakah momentum itu merupakan pergeseran paradigma ataukah penekanan nilai baru ke dalam cara pandang administrasi, namun yang pasti, perkembangan selanjutnya telah memberi warna pada bagaimana administrasi berjalan melalui fungsi-fungsi manajemen.

New public administration telah memperhatikan perangkat struktur dan manajemen sebagai strategi dalam memaksimalkan nilai-nilai keadilan dan prasyarat mewujudkan keadilan social melalui prosedur, mekanisme dan proses manajemen kemudian hari. Hal itu, memekarkan pengertian administrasi sehingga dapat ditemukan defenisinya dalam perspektif proses manajemen.

Pada perspektif proses itulah, manajemen didefenisikan sebagai tujuan administrasi yang dapat dicapai dengan cara-cara rasional, efisien dan efektif. Sebagai suatu sistem wewenang dan tanggung jawab, manajemen adalah pengambilan keputusan, agar tujuan dapat tercapai dengan 
sebaik-baiknya. Dalam pengertiannya sebagai kolektivitas, manajemen adalah setiap orang yang dalam administrasi itu bertugas dan bertanggung jawab atas pengarahan dan pengendalian kelompok orang-orang yang bekerjasama untuk mencapai tujuan yang telah ditentukan (Siagian, 1985). Sebagaimana halnya dengan batasan atau definisi tersebut, maka susunan perangkat fungsi-fungsi manajemen yang bersifat organik dengan singkatan POAC, menurut George R. Terry (dalam Siagian, 1985) adalah sebagai berikut: (1) perencanaan (planning), (2) pengorganisasian (organizing), (3) penggerakan (actuating), (4) pengawasan (controlling).

Para sarjana, telah merinci berbagai prinsip manajemen, baik yang bersifat umum maupun aspekaspeknya. Adapun prinsip-prinsip umum manajemen antara lain telah dirumuskan oleh Henry Fayol (dalam Siagian, 1985). Ia mengemukakan 14 prinsip sebagai berikut: (1) Pembagian pekerjaan, ini adalah prinsip spesialisasi, (2) Wewenang dan tanggung jawab, (3) Disiplin; (4) Kesatuan perintah, (5) Kepentingan umum lebih diutamakan ketimbang kepentingan pribadi, (6) Kesatuan arah, (7) Penghasilan pegawai, (8) Rantai berjenjang, (9) Ketertiban; (10) Kejujuran, (11) Kepastian masa jabatan pegawai, (12) Prakarsa, (13) Semangat, dan (14) Sentralisasi.

Baik menurut ilmu maupun praktek membuktikan bahwa administrasi publik intinya adalah manajemen, selanjutnya manajemen intinya adalah kepemimpinan bahkan lebih lanjut lagi inti dari kepemimpinan adalah hubungan kemanusiaan (human relations) dan terakhir adalah manusia (Siagian, 1982).

Penggerakan dapat diartikan sebagai pembimbingan, pembinaan dan motivasi, sehingga tidak terlepas dari hubungan kemanusian "human relations" dalam mencapai tujuan dalam mengembangkan sistem. Untuk itu manajemen memerlukan perencanaan, pengorganisasian, penggerakan dan pengendalian kegiatan-kegiatan dalam kerja sama itu, sehingga seluruh kegiatan menjadi efisien dan efektif dalam pencapaian hasil. 
Dalam proses manajemen, ternyata bahwa manusia sadalah faktor yang dominan dan menentukan. Manusia memiliki kemampuan paripurna seperti kecerdasan intelektual, kecerdasan emosional dan kecerdasan spiritual. Selain itu, juga memiliki kemampuan andalan dari segi fisik yaitu dapat melakukan kegiatan-kegiatan majerial, kegiatankegiatan fungsional dan teknis secara rasional, efisien, dan efektif.

Kompleksitas manusia menyebabkan pikiran dan perasaan sangat labil. Oleh sebab itu, keberhasilan manajemen memanfaatkan sumber daya manusia aparatur adalah ditentukan oleh kemampuannya menstabilkan jiwa atau pikiran dan perasaan manusia itu (Urwick, 1965). Teori ini memberikan gambaran bahwa manusia mahluk organisasional yang kompleks yang menyebabkan labilnya terbentuknya kebersamaan dalam organisasi. Sehingga dengan demi-kian, peran manusia dalam proses administrasi dan manajemen sangat mendukung tercapainya efesiensi dan produktivitas pelaksanaan tugas dan fungsi organisasi.

Fungsi manajemen yaitu merencanakan, mengarahkan, memotivasi, mengkoor-dinasikan, mengendalikan dan mengevaluasi kegiatan-kegiatan kerjasama manusia untuk mengemban visi dan misi organisasi yang telah ditentukan (Siagian, 1982). Bila dikaitkan dengan pengertian administrasi yaitu proses kerjasama sekelompok orang untuk mencapai tujuan secara rasional melalui pengaruh dan bimbingan serta pengarahan daripada pemimpin, maka hal ini dapat dikatakan bahwa pemimpin memberikan bimbingan, motivasi serta pengarahan kepada bawahan untuk mencapai tujuan. Dalam pengertian luas (administration) itu, adalah persamaan dengan kepemimpinan.

Menurut Urwick (1965) bahwa Kegiatan-kegiatan manajemen terlihat pada proses pelaksanaan fungsi-fungsi yaitu: (1) Forecasting, (2) Planning, (3) Organizing, (4) Directing, (5) Coordinating, (6) Controlling. 
Lebih fokus pada manajemen publik, fungsi manajemen menurut Syafiie (2006): adalah (1) Public planning, (2) Public actuating, (3) Public controlling, (4) Public coordinating, (5) Public leading, (6) Public motivating. Semua fungsi itu berkaitan satu dengan yang lain, sehingga merupakan satu kesatuan proses untuk mencapai sasaran manajemen yang telah ditetapkan. Penerapan fungsi-fungsi manajemen secara efektif tersebut akan berpengaruh terhadap pemberdayaan seluruh sumberdaya yang diperlukan. Semua masalah yang timbul diantisipasi melalui pendekatan kesisteman sehingga para administrator menganut prinsip systems thinking (Senge, 1995).

Administrasi unsur utamanya adalah kerjasama sekelompok manusia untuk tujuan tertentu, maka inti administrasi itu adalah manajemen, karena dengan manajemen kegiatan-kegiatan kerjasama itu lebih terarah, lebih terkoordinir dan terkendali. Pada awalnya ilmu manajemen dipelopori oleh Taylor \& Fayol (dalam Djamin, 1987) yang mengembangkan ilmu administrasi (manajemen umum). Perbedaan pengertian antara manajemen dengan adminis-trasi tidak terlalu jelas sehingga banyak pendapat yang mengatakan penger-tiannya sama dan dipakai sering bersamaan atau saling berganti. Perkembangan paradigma dan realita administrasi publik berbeda keadaan yang lampau dengan yang sekarang. Administrasi publik yang lampau banyak berorientasi pada kekuasaan, baik dipandang segi istitusi maupun dari segi pejabat, sekarang administrasi publik lebih banyak berorientasi pada pelayanan dan berperan menjalin kemitraan dengan pengusaha di bidang bisnis dan pada masyarakat umum.

Organisasi sebagai dimensi strategis administrasi publik, memerlukan kajian pokok tentang perilaku organisasi, karena masalah perilaku organisasi adalah masalah manusia, dengan alasan bahwa manusia adalah makhluk organisasional yang sangat kompleks baik fisiknya maupun psikhisnya (Siagian, 1982). 
Definisi administrasi publik yang dikemukakan oleh para ahli, rumusannya berbeda-beda satu dengan yang lain, namun pengertian dasarnya adalah sama. Ada yang menekankan pengertian administrasi publik yaitu kegiatankegiatan yang meliputi implementasi kebijakan pemerintah yang ditetapkan oleh badan-badan perwakilan politik. Namun secara global, didefi-nisikan sebagai suatu proses yang dipelaksanakan berdasarkan kebijakan pemerintah (Pfiffner \& Prethus, 1960).

Selain itu ada yang memandang administrasi publik itu sebagai admi-nistrasi dari publik (Administration of Public), dan ada yang memandang sebagai administrasi untuk publik (Administration for public) serta ada pula yang memandang administrasi oleh publik (Administration by public), dimana masing-masing pandangan itu mempunyai titik berat makna yang berbeda satu dengan yang lain (Keban, 2010).

Administrasi publik dalam implementasinya lebih mengutamakan public service atau pelayanan, walaupun dalam hal-hal tertentu prinsip ekonomi itu, kadang kala diperlukan. Menurut Widjaja (1999) Ruang lingkup administrasi publik sebenarnya sangat luas, yaitu: (1) Organisasi atau kelembagaan, (2) Manajemen atau ketatalaksanaan, (3) Admnistrasi kepegawaian, (4) Administrasi keuangan, (5) Administrasi perlengkapan atau peralatan, (6) Kesekretariatan atau ketatausahaan, (7) Tata hubungan, dan (8) Perwakilan atau hubungan masyarakat.

Kinerja pelayanan administrasi publik yang berkembang dalam "New Public Management" atau birokrasi moderen menurut (Vigoda, 2002) yang dituntut adalah: (1) Pemanfaatan manajemen profesional, (2) Penggunaan indikator kinerja, (3) Penekanan pada kontrol output, (4) Pergeseran perhatian pada unit-unit kerja yang lebih kecil, (5) Pergeseran pada kompetisi yang tinggi, (6) Penekanan pada gaya sektor swasta pada praktek manajemen, dan (7) Penekanan pada disiplin dan penghematan sumberdaya. 
Administrasi publik sebagai sistem adalah seluruh unsur-unsur atau komponen-komponen yang terkait satu dengan yang lain, saling berhubungan dan saling mendukung, sehingga merupakan satu kesatuan administrasi negara yang utuh dalam kesatuannya. Sumberdaya Administrasi publik selain SDM yang peranannya sangat penting dan dominan, maka sumberdaya lain seperti uang, alat, bahan, tempat, waktu dan yang tatkala pentingnya adalah informasi. Semua jenis sumberdaya itu harus di tata atau dikelola sebaik mungkin, sehingga pemanfaatannya lebih berdaya guna dan berhasil guna.

Administrasi publik dituntut memberdayakan sistem informasi untuk membantu para manajer dalam menyusun rencana, mengendalikan operasi-operasi. Sistem ini juga akan melengkapi para manajer keseragaman waktu yang tepat, sehingga mereka mampu mengambil keputusan yang tepat. Sistem informasi pada hakekatnya adalah keseluruhan jaringan informasi yang dibutuhkan oleh pimpinan untuk memperlancar pelaksanaan fungsinya terutama menyamngkut dalam hal ini fungsi pengambilan keputusan dalam rangka pemecahan masalah-masalah administrasi dan manajemen (Sugandha, 1997).

Administrasi publik tidak lagi diragukan peranannya yang sangat penting untuk mendukung dan mensukseskan pelaksanaan tugas-tugas peme-rintahan, melancarkan tugas pembangunan dan tugas kemasyarakatan berda-sarkan prinsip efisiensi, efektivitas dan produktivitas. Produktivitas merupakan interaksi terpadu secara serasi dari faktor esensial yakni investasi termasuk penggunaan pengetahuan dan teknologi serta manajemen. Mengenai efisiensi, efektivitas dan produktivitas administrasi publik biasanya dianggap indikator daripada kinerja individu atau kinerja organisasi. Sebetulnya ada kebenarannya, hanya saja kinerja individu atau organisasi harus terukur, sehingga dapat diidentifikasi kesenjangan antara terpenuhinya kinerja atau tidak. Kinerja administrasi publik masih didominasi oleh ukuran-ukuran kuantitatif dan cenderung melupakan indikator indikator kualitatif. 
Reformasi administrasi publik merupakan bagian yang tak terpisahkan dengan reformasi di bidang politik, ekonomi, sosial budaya, pertahanan keamanan, penegakan hukum dan lain-lain yang berkaitan dengan aspek-aspek kehidupan masyarakat. Reformasi administrasi publik hendaknya dilakukan secara terencana, terorganisisr dan terkendali, sehingga sungguh-sungguh dapat dibangun administrasi publik yang berkualitas dalam arti andal, profesional, dedikatif, bermoral, efisien, efektif, tanggap dan proaktif. Reformasi adminis-trasi publik secara total membutuhkan kepemimpinan yang komitmennya dijamin, etika dan moralnya dapat dipertanggungjawabkan serta pengetahuan dan keterampilan manajerialnya dapat diandalkan.

Masalah-masalah yang menjadi pokok perhatian administrasi publik ialah Public Policy. Bidang kajian ini amat penting bagi administrasi publik karena selain ia menentukan arah umum yang harus ditempuh untuk mengatasi isu-isu masyarakat, ia pun dapat dipergunakan untuk menentukan ruang lingkup permasalahan yang dihadapi oleh pemerintah. Selain itu, dapat pula dipergunakan untuk mengetahui betapa luas dan besarnya organisasi pemerin-tah. Masalah-masalah itu kadang-kadang rumit dan fundamental, sehingga memerlukan proses pemecahan yang rumit pula. (Thoha, 1997).

Deskripsi fungsi-fungsi manajemen untuk mencapai tujuan organisasi, dapat dilihat dari dua asfek utama yaitu: (1) Fungsi manajerial atau organik yang terdiri atas: (a) Perencanaan, (b) Pengorganisasian, (c) Pengarahan (motivasi/ penggerakan), (d) Pengendalian. (1) Fungsi operasional yang terdiri atas: (a) Rekrutmen, (b) Pengembangan, (c) Kompensasi, (d) Pengintegrasian, (e) Pemeliharaan, dan (f) Pemutusan hubungan kerja. 


\section{B. Teori dan Perspektif Manajemen}

a. Teori Insentif

Trend perspektif yang ditunjukkan oleh para teoritisi terdahulu dalam menjelaskan secara ilmiah ciri, sifat dan dimensi fenomena manajemen berkembang secara tegas. Sebagaimana Taylor, Fayol, Gulick dan Urwick fokus pada produktivitas dan pemudahan pekerjaan; metode kerja dan standard kerja; studi gerak waktu dalam melaksanakan pekerjaan (time and motion study) dan prinsif-prinsif kerja; setiap orang dalam organisasi (tinggi atau rendah), harus diberi perlengkapan kerja (yang standard) dan insentif yang tinggi agar hasil kerja berkualitas (Robbins, 2008: 222-232).

\section{b. Teori Hubungan Manusia}

Teori hubungan manusia digolongkan pula ke dalam asosiasi teori manajemen ilmiah. Teoritisi teori hubungan manusia yang menonjol antara lain Follet, Mayo, Reothlisberger mengetengahkan tesis pemikiran yang menekankan perspektif yang dikenal sebagai sanggahan terhadap teori finansial. Perspektif mereka ini berorientasi pada peningkatan produktivitas kerja, hubungan yang dinamis dan harmonis Kossen (1993: 93).

c. Teori Perilaku

Teori perilaku (Behavior Science) yang dipelopori antara lain oleh Chester L. Barnard dan Herbert Simon lazim disebut sebagai perspektif gabungan antara teori insentif dan teori hubungan manusia. Teori ini mengintegrasikan pandangan ilmu psikologi, sosiologi, ilmu politik dan ekonomi sekaligus. Perspektif teori ini fokus pada prilaku kerja yang kooperatif dalam organisasi formal (Works behavior in formal organizational). Lazim juga disebut teori organisasi perspektif perilaku yang menandai perubahan besar dalam perspektif teori organisasi sebab mengetengahkan pandangan organisasi sebagai sistem terbuka. 
Perspektif perilaku mengajukan tesis pemikiran yang menekankan bahwa produktivitas kerja individu akan membawa produktivitas kerja organisasi dan akan tergantung pada prilaku orang-orang dalamnya. Dimana perilaku orang, akan tergantung pada kebutuhannya dan hal itu berimplikasi pada peningkatan produktivitas organisasi. Meningkatkan produktivitas individu ditempuh dengan memberikan insentif sesuai dengan tingkat kebutuhannya (Robbins, 2008: 244).

Perspektif ini berkaitan dengan proses manajemen melalui, atau sebagaimana terminologi Davis (1989), human behaviour at work bahwa interaksi antar anggota organisasi (pegawai) merupakan perilaku dalam situasi kerja yang secara langsung memotivasi kerjasama dan produktivitas. 


\section{BAB III \\ PERKEMBANGAN GENERASI DAN \\ PEMIKIRAN MANAJEMEN}

\section{A. Generasi I (Jungle Management)}

Pada era ini, para teoritisi lebih memandang pekerjaan sebagai kegiatan yang dikerjakan sendiri, tidak ada catatan tertulis tentang apa yang telah, sedang, dan akan dikerjakan. Semua dicatat dalam ingatan orang-orang yang menjalankan manajemen. Pekerjaan dijalankan secara naluriah, mengalir bersama-sama orang yang saling bekerjasama. Prinsip yang lahir dan dikenal melalui era ini adalah doing thing by ourself (Robbins, 2008: 264).

\section{B. Generasi II (Management by direction)}

Manajemen sudah mulai kokoh sebagai sebuah ilmu. Pelopornya adalah Taylor (1856-1915) dan dikenal sebagai Bapak manajemen ilmiah. Konsepsi manajemen ilmiah dicirikan melalui penggunaan wewenang untuk mengarahkan personil organisasi dalam mencapai tujuan. Sering disertai penggunaan paksaan. Dalam konstelasi ini, personil organisasi kurang memiliki kebebasan untuk berkreasi dan belum memperhitungkan kepuasaan pelanggan maupun kepuasan anggota organisasi. Namun pada fase ini dimulai perkembangan teori-teori kepemimpinan yang dinamakan management by direction dengan prinsip doing thing through by the other people (Robbins, 2008: 265). 


\section{Generasi III (Management by targetting/management by objective)}

Generasi ini mengembangkan pandangan bahwa personil organisasi diberi kebebasan agar memiliki daya inovasi dan kreativitas. Kebebasan diimbangi dengan pemenuhan target-target pekerjaan yang ditetapkan secara kuantitatif untuk mencapai tujuan organisasi. Namun dalam realitas empirik praktek manajemen ini, target pekerjaan terlampau berat dan akhirnya membelenggu personil organisasi lalu kemudian menimbulkan stress. Pandangan ini dipeloporo oleh Peter F. Drucker dengan mengutamakan nilai produktivitas. Pada era ini, fakta tentang perlunya kajian terhadap aspek-aspek psikologis personil manajemen sudah mulai mengemuka (Robbins, 2008: 266).

\section{Generasi IV (Value creative management)}

Brian L. Joiner memiliki kontribusi besar dalam era ini. Pandangannya bercirikan (Primary hallmark) pemaduan antara kualitas, pendekatan ilmiah serta kerja tim dalam suatu segitiga yang dimanakan "Joiner triangle". Pandangan Brian difokuskan pada kualitas produk yang dihasilkan dalam rangka memberikan kepuasan pada pelanggan (Customer satisfaction) disertai kepuasan dari para personil organisasi. Dalam hal ini, kualitas yang dimaksudkan adalah sebagaimana yang didefenisikan oleh para pelanggan. Pencapaian kualitas dilakukan melalui berbagai pendekatan ilmiah yang berbasis pada penelitian. Pendekatan ilmiah direkomendasikan karena ia merupakan suatu proses belajar mengelola organisasi sebagai suatu sistem. Oleh karena itu, melalui pandangan ini, pengembangan proses berpikir serta pengambilan keputusan didasarkan pada data. Filosofi pandangannya berangkat dari rasa percaya pada setiap orang dengan memperlakukan manusia berdasarkan harga dirinya, kepercayaan dan rasa hormat serta bekerja atas dasar pendekatan menang-menang (Win-win approach). Pandangan Brian ini termasuk dalam manajemen kualitas total atau yang populer dengan sebutan Total quality management (Robbins, 2008: 267). 